\title{
Where The Tin Lizzy Took Us
}

\author{
William Matthew McCarter
}

\section{Introduction}

Contemporary community college students often have full time jobs while they are full time students and many of them are taking care of children or other family members while they work and attend school. In spite of the fact that they have little time to really reflect on their learning or the world at large because they are just too busy trying to keep the lights on, most of them manage to get their school work done and, for the most part, they do pretty good work. However, occasionally, things happen that make you wonder about this next generation of Americans and what our world is going to be like when they are in charge. I had one of those moments a few years ago at a school sponsored event.

During a faculty presentation on Black History Month, one of our college's students said, "I don't care about history. If it happened before I was born, it really doesn't matter." My first thought was to ask the student how she felt about Christianity. Our two thousand year wake for Jesus Christ certainly happened before she was born and was likely pretty relevant to her life whether she was a practicing Christian or not. At first, I was shocked that anyone enrolled in college would say something like that, but I did feel good that our students felt comfortable enough with our faculty that they could at least be honest. The student's comment was essentially that - brutal honesty. And, really, it shouldn't be that surprising that history is irrelevant to this generation. Russell Jacoby, Distinguished Professor of Critical Studies and author of Picture Imperfect: Utopian Thought for an Anti-Utopian Age writes that the belief that the future will be better than the present is gone. "Young people now seem to have a sense that living for today is about the best that they can do" Jacoby, 2007, xii).

My second thought in reaction to our student's claim about history was of Aldous Huxley. After all, the "messiah" of Huxley's Brave New World was Henry Ford and throughout the novel, a slogan that was attributed to Ford - "history is bunk" - is honored and elevated to the status of commandment. In Huxley's novel, Huxley was primarily concerned with some of the very things that I believe really impact our society in very profound ways - the fetish of youth and the dangers of mass consumerism. In addition, Huxley illustrated a mechanical and pharmaceutical manipulation of the human psyche, nearly predicting the arrival of genetic engineering and Prozac by nearly a century. Huxley seemed to be concerned with the industrialization and mass production of the early twentieth century and his concern was manifested in the form of pervasive references to his "mechanical messiah," Henry Ford. The "T" from Ford's Model T was a sacred symbol of Huxley's society and served as a kind of crucifix for the "priest of production" - those leaders that Huxley called Fords. In addition, Huxley marked time in history using "A.F" or "After Ford." Ford's Day was also celebrated in this Brave New World and seems to be both the 4th of July and Christmas in that society (Huxley, 2006; Jacoby, 2007).

Henry Ford, Dearborn, Michigan's favorite son and one of the industrial heroes of the 20th Century, once said "history is bunk. We want to live in the present. The only history that is worth a tinker's damn is the history we make today." One might argue that Henry Ford's idea of history being "bunk" is one of the things that make him an American. We Americans are not very good at thinking about history. We are such a young nation compared to other countries that, we really don't even have a history in the same way that other regions around the globe have a history. While Europeans living in Spain or France can trace their history back for nearly a thousand years, we have 1776. While nation's in the Middle East can say that they are living in "the cradles of civilization," we are the New World a modern world - the children of the Enlightenment. While aristocrats from other nations often have four or more 
names and the most important of those are their dynastic family names, in our supposed classless egalitarianism, we Americans call each other Hank and Dale. We Americans have a history but if there is a central theme to our American history, it is that we have a history of forgetting how to remember the past.[1]

This inability to remember the past is somewhat consistent with one of the premises of what philosophers (and perhaps historians) might call modernity. Richard Hooker, a professor at Washington State University, provides a concise and complex definition of modernity as simply being "the sense or the idea that the present is discontinuous with the past, that through a process of social and cultural change life in the present is fundamentally different from life in the past" (Hooker, 1999). From the beginning, our America has seen itself as being fundamentally different from the political and cultural traditions that came before it and perhaps this break with the past has contributed to what appears to be the disjointed constructions of our past.

As a country, we do not have a national epic like The Iliad or Beowulf. The closest thing that our nation has to a national epic is the narrative of the Lewis and Clark expedition and this narrative isn't so much a narrative about a culture or civilization, as it is a narrative about progress - a narrative of westward expansion. It is a narrative of a frontier that can be invented and reinvented by those who choose to settle there. Our national epic is ephemera and there is no greater break from tradition than that. Perhaps this break from tradition is why "history is bunk" and why we don't see a need to dig through the ash heap of our past. Perhaps it is unnatural for us to look toward history in critical reflection - it is not consistent with our modernist frames of reference or habits of mind. Then again, perhaps that is the very reason that we need to cultivate this kind of critical consciousness even more because this way of thinking is something that does not come natural to us. Perhaps this is why we should think about our own historicity to see just where Henry Ford's Tin Lizzy took us and where we go from there.

\section{| Henry Ford}

In many ways, Henry Ford's Ford Motor Company is the pinnacle of 20th century industrial manufacturing that produced revolutionary technological, social, and economic changes still being felt well into the 21 st century. In the first half of the 20th century, the skilled workforce of what had been a craft based production was usurped by the unskilled labor of mass production and new power relations were at first, constructed in the industrial workplace, and then throughout much of society. The transformation of a craft based production to mass production virtually created the market economy as we know it. These economies of scale were created by financially spreading the fixed expenses out over larger volumes of products in order to reduce unit costs. Through the exploitation of the division of labor by transferring the knowledge of production from the craftsman to the machine and by combining the logistical support for the enormous workforce necessary to create an economy of scale, Ford's model of mass production became the model for almost all of the industrial manufacturing in the 20th century. These economies of scale also engendered public policies, institutions, and government mechanisms that eventually led to what we would eventually become known as Fordism (Polyani, 1944).

Under Ford's mass production, not only were the parts interchangeable, but so were the workers. According to James Womack, in The Machine that Changed the World, mass production carried the division of labor to its ultimate extreme in that the assembler had only one task - to put two nuts on two bolts or perhaps to attach one wheel to each car. He assembly worker didn't order parts, procure his tools, repair his equipment, inspect for quality, or even understand what workers on either side of him were doing. The role of the assembly worker had the lowest status in the factory (1990). Womack goes on to add that in some plants, the management team actually told assembly workers that they were needed only because automation could not replace them yet (1990). Essentially, proponents of this mode of production believed that activities should be broken down into the simplest of steps and then controlled by management from up above.

By moving away from a craft based production where skilled workers had a great deal of control over their conditions of work, mass production shifted toward the use of less skilled labor operating machines that now performed the skilled labor of the craftsman giving the capitalists more control over the workplace. Prior to this paradigm shift from craft based production to mass production, workers often knew more about the workplace and the work that they were doing than the people who hired them. This gave these skilled workers a great deal of power. However, as the skills shifted from the workers to the machines that the workers operated, human judgment was replaced with rules, regulations, and a rigid structure. What would become known as Fordism was built on the 
increased mechanization of the labor process that led to capitalist control over the workplace.

The influence of the work of Frederick Winslow Taylor can be seen throughout the shift from craft based production to the mass production of what would later become known as Fordism. In 1911, Taylor published The Principles of Scientific Management where he devised a means of detailing a division of labor in time and motion studies and a wage system based on performance (what is commonly called "piece work" in the factory). The main elements of Taylor's work are time studies, standardization, task allocation, and detailing exactly what workers should be doing (Taylor, 1967). These elements were, for Taylor, the elements of the mechanisms of management. Taylor's work solved several problems for the industrialists of the early 20th Century. In craft based production, workers knew more about the work that they were doing that the industrialists who had invested in their labor. Through task allocation, management understood more about work in terms of the bigger picture than those who were actually doing the work. The workers on the assembly line knew just enough to do their job, but not enough to leave the factory as a craftsman or to be paid the premium that one would get if one were a craftsman.

The industrialists owned the means of production in that they owned the factory, but through the use of what would become known as Taylorism, the industrialists would also own the skills of labor because those skills would belong to the mechanisms of mass production and not the laborers who were doing the work. Antonio Gramsci, an Italian Marxist and philosopher, understood this too well. For Gramsci, "Taylor expresses the real purpose of American society - replacing in the worker the old psycho-physical nexus of qualified professional work, which demanded active participation, intelligence, fantasy, initiative, with automatic and mechanical attitudes" (Gramsci, 2002). "Taylorism" - the name for putting his principles into action - would go on to become the standard model for businesses worldwide.

\section{| Henry Ford's Tin Lizzy}

The early industrialization of America was very beneficial to the American states now commonly known as "The Rust Belt." America's waterways provided a natural transportation system to move raw materials from places like Minnesota's Mesabi Iron Range to manufacturing centers in places like Cleveland and Detroit. In addition, railroads could easily transport coal from places like West Virginia and Pennsylvania. In fact, railroad transportation was so important to the automotive industry in Michigan that many of the earliest automobile production plants were located in an area of Detroit known as Milwaukee Junction. It is here in Detroit, Michigan that we find Henry Ford near the turn of the century and in Milwaukee Junction that the invention that would change the landscape of American history and culture - the Model T Ford - was conceived and built.

After failing at two separate attempts to start a manufacturing company, success finally came to Henry Ford in 1903 when he formed the Ford Motor Company. In 1908, Ford introduced the Model T Ford - The Tin Lizzy - and it was a huge success because of its durability and technological innovations. In contrast to earlier manufacturers, like Ransom Olds, who sought to build playthings for the rich, Henry Ford said "I will build a great motorcar for the masses... constructed of the best materials, by the best men to be hired, after the simplest designs that modern engineering can devise... so low in price that no man making a good salary will be unable to own one and enjoy with his family the blessing of hours of pleasure in God's great open spaces" (html). However, Ford had a problem: his motorcar cost $\$ 825$ dollars in 1908. In order for his design to be the "motorcar for the masses," Ford had to find a way to bring the costs down so that he could sell his product for less money and more people could afford to own one.

Ford and his engineers were able to raise their production levels of the Model $\mathrm{T}$ and also to reduce costs in the years following its debut in 1908. Ford's initial assembly plant was located on the corner of Piquette and Beaubien Streets in Detroit. It is on the second floor of the Piquette Plant that Ford found a way to solve his production problems and fulfill his dream of creating a "motorcar for the masses." Legend has it that Henry Ford visited a meat packing plant near Chicago where they employed some of Taylor's principles of scientific management. In this particular meat packing plant, the animal carcasses hung on hooks that moved throughout the factory on a conveyor system. Instead of each worker being a trained butcher that could cut up the entire carcass, each of the workers was trained to do one particular task in the butchering process. So, instead of having a skilled butcher that was capable of doing the entire job of cutting up the carcass, the factory employed several unskilled workers who could only create T-Bone steaks, roasts, or hamburger. When Henry Ford returned to Detroit, he gathered his management team on 
the second floor of the Piquette Plant and pulled an automobile chassis across the floor while the management team assembled an entire Model T Ford through a series of simple steps.

Henry Ford quickly built his Highland Park Plant and it is in this plant that Ford and his engineers are credited with creating the model of mass production that used the first moving assembly lines in 1914. Ford's assembly line increased labor productivity tenfold and permitted stunning price cuts in The Tin Lizzy - from 780 dollars in 1910 to 360 dollars in 1914. After a conveyor belt was added in 1916, the Highland Park Plant produced more than 700,000 Model T Fords. This brought the price down to 290 dollars by 1924 and by 1927, Ford Motor Company had produced more than 15 million Model T Fords. In fact, by 1927, Ford Motor Company could produce a car every 60 seconds. After that, the term Fordize was used to standardize a produce and manufacture it by mass means at a price so low that the common man can afford to buy it (Abernathy, 1978; Hounshell, 1984). After moving from the Highland Park Plant to the Rouge Plant, Ford ultimately made everything he needed for his cars from the raw materials to the finished product. Iron, coal, rubber, and other raw materials would come into one end of the manufacturing facility and an automobile would come out of the other side. Ford developed this idea of vertical integration for several reasons but two of these stand out more than others. First, Henry Ford had perfected mass production techniques so well that he could manufacture the parts that went onto his automobiles for less money than it would take to purchase them from a supplier. In addition, Ford could coordinate the flow of raw materials and meet the demands of his assembly lines much easier than the suppliers who used to provide him with parts for his assembly line (Chandler, 1977).

What we must realize is that the system of mass production is far more complex than just a new way of manufacturing products. This new industrial technology also impacted the early 20th Century socially in terms of the transformation of work. The early automobile manufacturers (Ford included) primarily "assembled" parts from an outside supplier. Often the parts weren't machined exactly right and they had to be filed down and "worked" into the final assembly. As the manufacturing technology got better and these parts became more standardized and reliable, this was no longer necessary and as a result, these skilled machinists could be replaced by assemblers. Ford's institutionalization of Taylor's principles of scientific management helped to usher in a whole new set of institutionalized relationships between capital and labor and among capital, labor, and political institutions as well. Antonio Gramsci was perhaps the first person to recognize and write about the potential political and cultural significance of what he called "an ultra-modern form of production and of working methods" (Gramsci, 2002). The institutionalization of this system of mass production required capital to exercise a combination of force and persuasion in the work place and, as a consequence, this new kind of capitalism became embodied in cultural practices and social relations that would extend far beyond the workplace.

For example, those machinists who had once been relied upon to solve problems and who had once had a great deal of autonomy over their work suddenly became assemblers who put nut number 86 on bolt number 86 in a regimented and structured assembly process. This assembly process of tedious and repetitive work led to workers being alienated from their work. Unlike skilled craftsman type work, assembly work was not very rewarding. Professor Stephen Meyer III, author of The Five Dollar Day: Labor Management and Social Control in The Ford Motor Company, talks about this when he writes that one Ford worker commented, "If I have to put nut number 86 on bolt number 86, 86 more times, I am going to be nut number 86 in the Detroit Mental Hospital" (Meyer, 1981). Assembly line work is unpleasant in a mass production environment. It is physically demanding, requires high levels of concentration, and can be excruciatingly boring. As a consequence, Ford experienced very high labor turnover, 380 percent in 1913. (Even today, double-digit absenteeism is common in mass-production assembly plants, necessitating a buffer stock of utility workers, who fill in for the assemblers that fail to show up at the start of each shift).

As a result of this changing nature of work, Ford and the other auto makers had to find a way to deal with their huge turnover and absentee problem in their laborers. According to the somewhat stylized facts, Ford, believing "men work for only two reasons: one is for wages, and one is for fear of losing their jobs," dealt with labor turnover by doubling pay to $\$ 5$ a day; that other manufacturer's emulated Ford's wage policies along with his production methods; and that eventually all employers were forced to bring wages into line with those who offered unskilled labor in manufacturing. In other words: premium pay for putting up with what Gramsci described as mass production's "monotonous, degrading, and life draining work process" (Gramsci, 2002). Ford was partially successful in that the rate of turnover fell from $370 \%$ to $16 \%$ in 1915. However, when the labor force got tight in Detroit during World War I and the war inflation took its toll on the value of wages, Ford's 5 Dollar Day no longer meant anything to workers and increases in the wages at the plant would not produce the increased productivity that Ford was looking for. In the mid 1920's, one production worker described the relentless pace and intense effort which his job required, and the 
consequences of failing to meet those standards: 'You've got to work like hell in Ford's. From the time you become a number in the morning until the bell rings for quitting time you have to keep at it. You can't let up. You've got to get out the production... and if you can't get it out, you get out" (quoted in Rupert, 1995: 111). In a few years, the Great Depression would come to the United States. Michael Aglietta suggests that the Great Depression came out of the uneven early development of intensive accumulation, revolutionizing production in the US without simultaneously transforming consumption and the living conditions of the working class (Aglietta, 1979). Although Henry Ford sought to create an automobile "so inexpensive that everyone could own one", that was not the case with the plethora of consumer goods available in the 1920's. Aglietta claims that the result of class inequality and exploitation was a catastrophic economic imbalance as the rapidly growing sector of production outpaced consumption (Aglietta, 1979). As a result of the Great Depression and the rise of labor unions, the social institutions of mass production began to emerge in the early 20th century. The social struggles of the 20's and 30's extended into the post World War II era and the social institutions of mass production - what we now refer to as Fordism - emerged.

\section{From Dirt Roads to Route 66: Fordism in Post War America}

The term "Fordism" refers to the system of mass production and mass consumption that was characteristic of the developing economies from the 1940's through the 1960's. Under Fordism, the science of mass production combined with the social phenomenon of mass consumption to produce sustained economic growth and widespread material advancement. For Michael Aglietta, Fordism was the regulative principle of a macro economic and social regime of accumulation involving very specific forms of capitalist production as well as social consumption norms (Aglietta, 1979). Essentially, Fordism led to the construction of new power relations in the workplace and the promise of massive increases in productivity led to the widespread imitation of Fordist modes of production. In addition to these key elements in manufacturing, there were also key elements in terms of labor and its politicization. In the post war years, trade unions were subdued by management. Instead of trying to subdue the unions through force, the capitalists subdued the unions through prosperity. Workers were offered a higher standard of living than they might have gotten before these Fordist principles were adopted throughout the manufacturing sector of America's economy. In the post war years, the mass production of Ford was synthesized with Taylor's principles of scientific management and John Maynard Keynes economic policies to produce a society in which nearly all of those living in that society functioned within the Fordist superstructure.

John Maynard Keynes' economic theory served as the vehicle in which Fordism could be spread throughout the United States. During the Great Depression, classical economic theorists defined economic collapse as simply being a lost incentive to produce. They believed that mass unemployment was caused only by high wages. For these classical economists, the solution to our economic problems was to cut wages. John Maynard Keynes saw wages as being much more complicated than these classical economists. Keynes argued that in order to boost employment, real wages would have to go down and would have to fall more than prices. This would reduce consumer demand and would likely make matters worse. No one really listened to Keynes in the early years of the Depression. However, after the recession of 1937, Franklin Roosevelt launched a \$5 billion dollar spending program in the spring of 1938 . This magnified the role of the federal government in the national economy and would have a profound effect on the role that the national government would play in economic policy for much of the remainder of the 20th century (Keynes, 2002).

In addition to Roosevelt adopting Keynesian fiscal policy, he also contributed to the passing of The Wagner Act and the creation of National Labor Relations Board. The Wagner Act is a kind of "bill of rights" for American workers and led to the expansion of labor unions like the UAW, the AFL-CIO, and the Teamsters Union from the late 1930's through the 1960's. The attack on Pearl Harbor and America's subsequent involvement in World War II led to increasing government partnerships with business in the "war economy" with government bankrolling business. Keynesians later argued that by spending vastly more money - using "fiscal policy" - the government could stimulate the economy through the "multiplier" effect. In the post-war years, Keynes's policy ideas were widely accepted around the globe. In this era of new liberalism and social democracy, most western capitalist countries enjoyed low, stable unemployment and modest inflation. Once Keynesian economics was adopted, economic policy placed an emphasis on consumption or consumerism.

Under Fordism, laborers were not required to be skilled labor because under Henry Ford's model of mass 
production, the knowledge was transferred from the worker to the machine. This doesn't necessarily mean that the workers had to be unskilled or that the workers were uneducable. The workers could be skilled workers and many of these workers were, but their skills were not needed in the plant because the skill resided in the machine and not the worker. While these workers could be relatively unskilled, they could form unions and, as a result, earned relatively high wages. Most employees in a Fordist structure were able to purchase the products they produced and the Keynesian economic policies of the federal government protected domestic markets from outside competition that created a stable market for those products.

William Levitt, the father of modern American suburbia, once said, "No man who owns his own house and lot can be a communist. He has too much to do." [2] Not only was Fordism an innovative business practice for manufacturers and the standard economic model for much of the post war Western world, but it also served as a bulwark against communism during the Cold War. Mark Rupert makes this point abundantly clear when he writes: "In the postwar context of Cold War fears, and access to an unprecedented affluence, such challenges were contained within the bounds of a vision of liberal capitalism as the social system best able to secure - on a global scale - individual rights and liberties and a more generalized prosperity" (Rupert). The unions were, essentially, junior partners of the state and capital in a venture to reconstruct the capitalist world order.

However, the ability of these workers (who despite their talents) were doing unskilled labor in the factories to make substantial gains in terms of wages and benefits was largely dependent upon their political power. After the Wagner Act passed in World War II, workers had a tremendous amount of political power. During the war, because America was at or near full employment in order to produce products for the Department of Defense, workers also had a tremendous amount of political power. By the 1950's, the rise of mass production had made industrial workers the largest single group in nearly every developed country in the West. Organized labor was the political backbone of the postwar Keynesian liberal democracy. Because of the marriage of Ford's mass production and Keynesian economics, nearly half of the world's industrial production came from the United States. This was the economic engine that rebuilt Europe as a result of the Marshall Plan and supported the already emerging military-industrial complex and consumer society of the late 20th and early 21st centuries (Aglietta, 1979).

Fordism began to break down in the late 1960's and America's industrial production has been in decline since 1973. Since that time, Western economies have experienced slow or no economic growth, rising inflation, and growing unemployment. Fordism, supported by Keynesian economic policies, was beginning to reach its limits. Once the economy started slowing down, real wages could not continue to grow and capital began an assault on labor. This is the very thing that Daniel Bell envisioned in his book The Coming of Post-Industrial Society. Bell argued that post-industrialism would be information led and service oriented. Bell also asserted that the post industrial society would replace the industrial society. For Bell, there are three components to a post industrial society: 1.) a shift from manufacturing to services; 2.) the centrality of the new science based industries and 3.) the rise of new technical elites and the advent of a new principle of stratification (Bell, 1976). Antonio Gramsci also discussed this in his Prison Notebooks, when he writes that the current means of production and political economy will "be superseded by the creation of a new psycho-physical nexus, both different from its predecessor and superior. As a consequence, a part of the old working class will be eliminated from work, and perhaps from the world" (Gramsci, 2002). As a result of the globalization of capital and labor, Fordism is giving way (if it hasn't already completely surrendered) to Daniel Bell's post industrial society. The Cold War is over and, as a result, the prosperity that labor has enjoyed is evaporating as well. Labor no longer needs to be the junior partner of government and industry.

The new junior partners are all members of the World Trade Organization. Because of the role that the WTO plays in economics, the United States and some of the other developed nations have withdrawn from the economic sphere. What was once called "political economy" is now just economics. Because of this newly discovered global laissezfaire, the economies of developed nations have shifted from being grounded in manufacturing to being increasingly dependent upon the service sector and the knowledge sector for economic growth. Meanwhile, manufacturing has moved away from the west into developing nations. One example of this phenomenon of deindustrialization in developing nations is the closing of eleven automobile plants in Flint, Michigan and the opening of eleven new plants in Mexico. Because of these seismic shifts in the global economy, Americans increasingly realize that there is no connection between corporate profits and rising standards of living and that their ability to have any control over these economic decisions is limited at best. America may have driven the Tin Lizzy through the 20th century and America may have gotten its kicks on Route 66, but now, in the 21st century, America is broke down in Barstow. 


\section{| Walking across the California Desert}

While Ford's mass production helped the Ford Motor Company to "produce a motorcar for the masses," and the inexpensive consumer goods that came as a result of Fordism, these things have not come to us without costs. Huw Beynon illustrates one of these costs in his book, Working for Ford. Beynon explains that working in a car plant involves coming to terms with the assembly line. 'The line never stops,' you are told." While this kind of mindless work may be suitable for someone who is functionally illiterate or unthinking, (at least according to Frederick Taylor's research on scientific management) most, if not all, workers have to force themselves to temporarily become more like the unthinking machine demanded by Taylorism. Beynon explains that when he is at work, his mind is a blank. In fact, he makes it go blank in order to deal with the mundane and repetitive tasks he must endure to work at Ford (Beynon, 1975). Now, we must ask ourselves: "What kinds of literacy are necessary to work in a factory that produces a car every sixty seconds and how do people learn that literacy?" The historian, Howard Zinn, makes the connection between education and economics when he writes "it was in the middle and late nineteenth century that high schools developed as aids to the industrial system" (Zinn, 2010, 263). Zinn supports his argument with the work of Joel Spring, author of Education and the Rise of the Corporate State. For Spring, "the development of a factory-like system in the nineteenth century schoolroom was not accidental" (Zinn, 2010, 263).

For Spring, "the spread of public school education enabled the learning of writing, reading, and arithmetic for a whole generation of workers, skilled and semiskilled, who would be the literate labor force of the new industrial age. It was important that these people learn obedience to authority" (Zinn, 2010, 263). This kind of literacy is a literacy of obedience. It is a compliant literacy that emphasizes following instructions and doing what is required.[3] While this kind of literacy might have worked for Ford and Taylor, it didn't necessarily work for their employees. Nor does it work for us now. There has been significant research on Fordism and consumerism and what it has meant for 20th century America. These studies discuss the movement from craft based production to mass production and even the move away from industrialism and toward a post industrial society. While the Tin Lizzy has taken us through the million miles of changes that society experienced during the 20th century, perhaps the most important American landscape in the rear view mirror is the landscape of our own thought and how we approach our own thinking.

This leads us back to our student who cared so little for history. I wonder if it was the economic uncertainty that seems to mark our particular time and space in the world that causes young people to enter "the era of acquiescence, in which we build our lives, families and careers with little expectation the future will diverge from the present" (Jacoby, 2007, xi) or, if it is, in part, the result of what Paulo Freire called the banking concept of education. Freire writes "in sum: banking theory and practice, as immobilizing and fixating forces, fail to acknowledge men and women as historical beings" (Freire, 2002). We must remember that throughout the journey riding the Tin Lizzy through the 20 th century, we have two very dominant social forces at work. First we have the Fordist and Taylorist manufacturing principles coupled with the Keynesian economic principles. In addition, we have an education system that, according to Joel Spring, was conceived with the goal of producing an industrial army of workers to keep the wheels and gears of industry turning. Men and women were there in the factory because they were not quite machines and there weren't machines that could do this "not quite machine" work. An education "based on a mechanistic, static, naturalistic, spatialized view of consciousness" (Freire, 2002) was the education that was necessary to create a compliant and obedient workforce. If we accept that Fordism lies within the economic base of any given 20th century capitalist society, then we also must realize that the institutions in the superstructure (especially the institutions that educate) are there to reinforce the economic base. Could it be that this model of education "based on a mechanistic, static, naturalistic, spatialized view of consciousness" (Freire, 2002) coupled with the expectation that the future will not be any different than the present (Jacoby, 2007) have contributed to the death of our conception of history?

The 1970's marked the beginning of a period of slower growth and increasing income inequality. One could attribute much of the income inequality to the shift toward a post industrial society. Fordism has been transformed into new manufacturing principles based on a flexible system of production that comes out of the Japanese management system. These flexible systems of production are characterized by drastic reductions in information costs and overheads, total quality management, just-in-time inventory control, and leaderless work groups. These changes in production have also led to changes in consumption. These changes include the globalization of consumer goods markets, faster product life cycles, and greater product/ market segmentation and differentiation. In short, Fordism has been replaced with a system of production that we could call "Toyotaism." Essentially, the entire post war economy has undergone what Thomas Kuhn, the author of The Structure of Scientific Revolutions, calls a 
paradigm shift which is a term that he uses to explain how the nature of inquiry within a particular field is abruptly transformed (Kuhn, 2002). In order for this to happen, we have to reach some kind of critical mass in which the current way of thinking breaks down and needs to be re-evaluated.

Capital, with the help of its political institutions, has already undergone this paradigm shift. However, although the social, culture, and political capital of labor is at an all time low (and doesn't appear to be rebounding from this steady decline), the best thing that labor can come up with in terms of ameliorating its condition is a nostalgic return to the halcyon days of organized labor. Essentially, all labor seems to be capable of is conceiving of a more liberal society firmly grounded in Fordist modes of production and Keynesian economics. In an age of what seems like a constant state of permanent emergencies, we have become utilitarian in our efforts to fix what we have instead of reinventing the here and now. While it goes without saying that the kind of society that we want - the kind of society that we need - cannot be achieved without a strong economic base, we cannot ignore the globalized marketplace in which any nation's success depends on the innovative conceptual, creative, and technical skills of its workforce. This is the challenge of our moment in history. Our economic, political, and social models have been collapsing for quite some time and are giving way to something else as we move further into a globalized post-modern, post-industrial world. While, arguably, we, as a society, have been trying to come to terms with that shift economically and politically, our way of approaching education has not kept pace with these other paradigm shifts.

One of my former colleagues once said something that I will never forget. He said, "We know that there are going to be jobs in the future, but I don't think that we can say what these jobs are going to be or even what to call them." He went on to add, "Teaching students today is a lot like training athletes for the Olympics... only we don't know what event we are training the athletes for... we don't know whether to tell them to go run, go swim, or go out into a field and throw stuff." [4] Twenty years ago, if someone had told one of my contemporaries, "Don't bother getting that job at the checkout line at the store. There's no future in that. It won't be long before people will just check themselves out and no one will need you to do your job," I imagine that they would think whoever said that to them was crazy. But it happened and who's to say that something like that can't happen in the future. We don't know what event that students will be competing in, but we do know that a better educated and more highly skilled population will be able to deal more effectively with change and if we know nothing else, we know that things change. We also know that education creates the kind of self efficacy that helps with one's ability to adapt. We also know that education makes it easier for individuals to learn skills related to their chosen careers (or the careers that are imposed upon them because of the economy) and improves their ability to learn while they pursue those careers. Therefore, in light of what we know about education and in light of what Joel Spring wrote about education being an aid to the industrial system, then we should have a system of education in place that mirrors the paradigm of "Toyotaism" that seems to be the mode and means of production in the 21 st century.

If we are willing to accept the premise that education should mirror our economic paradigm (and I realize that most of us would say that it shouldn't), we have to wonder why there are so many Fordist elements in public education. Perhaps the most obvious example of these Fordist elements is the national standardized testing of No Child Left Behind (I like to call it "No Child Left Untested"). These standardized tests remind us of what Paulo Freire called "the banking concept of education." In an age where conceptual skills, problem solving skills, and creativity are the jobs skills necessary to compete as a knowledge worker in the new economy, multiple choice tests that barely register on the "identification" domain of Benjamin Bloom's Taxonomy of Cognitive Domains seems like nothing more than an educational relic of our Fordist past that one might find in The Henry Ford, a museum of Americana in Dearborn, Michigan. [5] Instead, we find these things in the thousands of classrooms in America's public schools and from the time that children enter kindergarten until they graduate from high school, they are taught that this relic is the sole measure of their success or failure. We are still teaching the literacy of obedience and compliance - a Fordist industrial literacy - in a post-Fordist post-industrial world. Students who say "if you will just tell me what to do, I'll do it" or "I did what you told me, why didn't I get an 'A"' demonstrate the degree in which this compliant literacy permeates their conception of thinking and informs their thinking of what it means to be educated.

This, in turn, leads us to wonder "If we are clearly in a post-industrial paradigm, why are we still imposing a literacy of obedience and compliance on our potential workforce?" The answer to that question, I believe, is that it is more essential for government (and the capital that owns government) to create a compliant and obedient society than it is for government to create a society of knowledge workers for the new economy. With a little help from government, capital has, thus far, been able to import the knowledge workers that they need to carry out their business plans. And, thanks to the technological innovations in telecommunications, it is now easier to outsource 
the jobs than it is to import the knowledge workers. Factory schooling for the masses may be inappropriate for the average worker in our post-Fordist age, but as long as it works for capital and enables our political institutions to maintain control of the masses, then it will likely persist. Our only real innovation in terms of education is using new technology to do the same thing that we have always done. In the last ten years, we have heard a lot of talk about computer literacy, however, computers only enable us to continue eliminating real content in terms of what students learn and reduce their learning to an exercise in how well they can finesse a machine. It's like shop class only cleaner. In a time when we should be trying to find ways to facilitate creative thinking, the factory that is public education only seems to be stifling it more.

In the late 19th and early 20th century, compliant literacy worked. Many of the jobs that were available were factory jobs that required very little, if any critical thinking skills and a lot of obedience. While we, as a society, try and figure out how we are going to deal with globalization, post-industrialism, and all of the other challenges of history, we also have to figure out how to equip the next generation of Americans with the kind of literacy that is compatible with that world so that they can transform their communities economically, politically, and socially. The quick answer to that is "higher education." However, many of those students from the culture of poverty or from working class families have a difficult time making the leap from a compliant literacy that stresses obedience to the kind of literacy that is necessary to become an autonomous thinker in the 21 st century. Adult students returning to school because the job that they used to have no longer exists are also challenged because, chances are, that student has spent several years in a routine production or in person service job that stressed obedience. If these students are ever going to take control of their lives and make things happen for them instead of waiting for things to happen to them, they must learn a literacy that stresses autonomous thinking and problem solving skills. The question is "how do they do that?" In The Structure of Scientific Revolutions, Thomas Kuhn argued that it is not possible to understand one paradigm through the conceptual framework and terminology of another paradigm. Albert Einstein concurred with Kuhn when he said "problems cannot be solved by the same level of awareness that created them."

So, how do we, as a society, move beyond our current level of awareness? For Paulo Freire, the answer to these questions lies within "critical consciousness." We need to "have a deepened consciousness" of our own situation so that we can "apprehend that situation as an historical reality susceptible to transformation." And we must take our own historicity as a starting point for that transformation. This is precisely why we need history. We must realize that history is not only about names and dates and wars and revolutions, but it is also about the way we think and imagine. Henry Ford might have said "history is bunk," but I am not entirely sure if he would agree that history doesn't matter. If history didn't matter to Henry Ford, then why did he collect so many artifacts? Why did he have a Greenfield Village? Surely there must have been something about the past that Ford thought was worth remembering and preserving? I would argue that history was very important to Henry Ford and that when Ford said "history is bunk" what he really meant was that while our lives may have been shaped by our history, our life is not determined by that history. This interpretation of Ford's assertion that "history is bunk" fits in with Paulo Freire's idea that people must "perceive their state not as fated and unalterable, but merely as limiting - and therefore challenging" (Freire, 2002). We are not predetermined by our history and that is why "history" is bunk, but at the same time, we need history in order to facilitate our own critical consciousness. We need history to do cultural work. We need to, as Freire says, "have a deepened consciousness" of our own situation so that we can "apprehend that situation as an historical reality susceptible to transformation" (Freire, 2002). We need history, but as Nietzsche says, "not in the way a spoiled loafer in the garden of knowledge needs it" (Nietzsche, 2010).

For Walter Benjamin, articulating the past historically does not mean to recognize it "the way it really was. It means to seize hold of a memory as it flashes up at a moment of danger" (Benjamin, 1968, 255). Almost daily, we are reminded that we are living in dangerous times and our history - the history of the American century - is most definitely flashing up in the moment of our danger. It is up to us to seize hold of the memory of what it was like to think, to imagine, and to dream. The Tin Lizzy may have taken us across the 20th century and it may have been a good car, but now that we are broke down in Barstow, it may be time for us to start walking across the desert. While Henry Ford might have thought that "machinery is the new messiah" in the early 20th century, here and now in the 21 st century, nearly a hundred years later, this deity's seat on the throne is tenuous at best because a machine cannot yet imagine, and despite being subjected to nearly a hundred years of compliant literacy, we still show signs of imaginative thinking. This imaginative thinking is the single candle that lights up the dark room of our own transformation.

In We the Living, Ayn Rand's character, Kira Argounova says "whoever places his highest conception above his own possibility thinks very little of himself and his life. It's a rare gift, you know, to feel reverence for your own 
life and to want the best, the greatest, the highest possible, here, now, for your very own.”[6] Kira is oppressed by Russian communism; we are oppressed by fascist corporatism. Perhaps that oppression was more palatable when it was coupled with Fordism, Keynesian economics, and consumerism; however, our oppressors appear to no longer need a middle class in order to function and remain profitable. As a consequence, they no longer need Fordism or Keynesian economics. If our global economy continues on its race to the bottom in terms of wages, there will no longer be any consumerism either and we will be left with nothing but our oppression and our oppressors. We will also be left with the machines. However, isn't it about time that we walked away from this new messiah? Isn't about time for us to pronounce this god dead? Isn't it time for us to, as Kira says "imagine a heaven and then not to dream of it, but to demand it?" In order to do this, we must accept that if we are going to make demands for ourselves, we must first make demands of ourselves. We must cultivate a transformation in our own thinking so that we can conceive of a journey to a destination that is beyond where the Tin Lizzy took us.

\section{Endnotes}

1. Because of a grant from the National Endowment for the Humanities, I was able to study the legacy of Henry Ford in Dearborn, Michigan in the Summer of 2006. Much of the thoughts that I have about Ford and Fordism were synthesized from discussions that took place during the various workshops and lectures that occurred during this study.

2. Levitt's suburban track housing is probably the pinnacle of mass production. Levittown is also probably the pinnacle of the 1950's conformity as well.

3. I am deeply indebted to my former colleagues at Mid Michigan Community College. Barry Alford, Lucia Eldon, Jim Vandermey, and Bill Reader have all been a part of lengthy discussions about topics like compliant literacy, learned helplessness, and resistance in the composition classroom.

4. My former colleague Chuck Bowden, Professor of Sociology at Mid Michigan Community College, used this phrase as an argument for learning the humanities and social sciences.
5. For more on Benjamin Bloom's taxonomy, see http:// officeport.com/edu/blooms.htm

6. I know that it must be a real shift to move from Fordism to Rand, however, I did this with real purpose. The right wing talking heads are always talking about "going Galt" and it appears that the moneyed interests are doing just that because no one is loaning anyone any money these days. However, I do not see this early Rand text as being pro capitalism as much as I see it as being anti-oppression. Perhaps, we should try and reframe Rand's message so that she appears to be more anti-Fordist than the prophetic priestess of American capitalism. Other than "reason," you really don't see Rand championing much of anything. While I can understand the argument that Fordism is not reasonable in that it doesn't really promote thinking, I am not sure that I can understand how our global fast capitalism can be any more reasonable than Fordism.

\section{References}

Abernathy, W. (1978). The Productivity Dilemma: Roadblock to Innovation in the Automobile Industry. Baltimore: Johns Hopkins.

Aglietta, M. (1979). A Theory of Capitalist Regulation: the US Experience. London : Verso.

Bell, D. (1976). The Coming of Post-Industrial Society: A Venture in Social Forecasting. New York: Basic Books.
Benjamin, W. (1968). Illuminations: Essays and Reflections. New York: Schocken.

Beynon, H. (1975). Working for Ford. London: EP Publishing.

Chandler, A. D. (1977). The Visible Hand: The Managerial Revolution in American Business. Cambridge, MA: Belknap. 
Freire, P. (2002). The Banking Concept of Education. Retrieved December 12, 2010, from Marxist Archives: http://www. marxists.org/subject/education/freire/pedagogy/index.htm

Gramsci, A. (2002). Antonio Gramsci’s Prison Notebooks. Retrieved December 12, 2010, from Marxist Archives: http:// www.marxists.org/archive/gramsci/prison_notebooks/index. htm

Hooker, R. (1999, July 14). General Glossary. Retrieved December 12, 2010, from The Crisis of Modernity: http://www.wsu. edu/ dee/GLOSSARY/MODERN.HTM

Hounshell, D. (1984). From the American System to Mass Production, 1880-1932. . Baltimore: Johns Hopkins Press.

Huxley, A. (2006). Brave New World. New York: Harper Perennial Press.

III, S. M. (1981). Professor Stephen Meyer III, author of The Five Dollar Day: Labor Management and Social Control in The Ford Motor Company . New Yorkl: SUNY Press.

Jacoby, R. (2007). Picture Imperfect: Utopian THought for an Anti-Utopian Age. New York: Columbia University Press.
Keynes, J. M. (2002). The General Theory of Employment, Interest and Money. Retrieved December 12, 2010, from Marxist Archive: www. marxists.org

Kuhn, T. (2002). The Structure of Scientific Revolutions. Retrieved December 12, 2010, from Marxist Archive: http:// www.marxists.org/reference/subject/philosophy/works/us/ kuhn.htm

Nietzsche, F. (2010). On The Uses and Abuse of History for Life. Retrieved December 12, 2010, from On The Uses and Abuse of History for Life: http://records.viu.ca/ johnstoi/ Nietzsche/history.htm

Polyani, K. (1944). The Great Transformation. Boston: Beacon Press.

Rupert, M. (n.d.). Crisis of Fordism. Retrieved December 12, 2010, from Digital Fordism: http://www2.cddc.vt.edu/digitalfordism/fordism_materials/rupert.htm

Taylor, F. W. (1967). The Principles of Scientific Manamement . New York: Norton.

Zinn, H. (2010). A People's History of the United States. New York: Harper. 
